\section{Risk and protective factors for non communicable diseases in the Belo Horizonte population: Vigitel 2008}

\section{Fatores de risco e proteção para doenças crônicas não transmissíveis na população de Belo Horizonte: Vigitel 2008}

\section{Bruna Mara Duarte' \\ Regina Tomie Ivata Bernal"}

\section{Deborah Carvalho Malta','ו!}

'Nurse School of Universidade Federal de Minas Gerais - Belo Horizonte (MG), Brazil.

"Center for Epidemiological Research in Nutrition and Health of Universidade de São Paulo - São Paulo (SP), Brazil.

"'Ministry of Health, Secretariat of Health Surveillance, General Coordination of Diseases and Non Communicable Diseases - Brasília (DF), Brazil.

Corresponding author: Bruna Mara Duarte. Escola de Enfermagem da Universidade Federal de Minas Gerais. Avenida Professor Alfredo Balena, 190, Centro, CEP: 30130-100, Belo Horizonte, MG, Brasil. E-mail: brumadu@yahoo.com.br

Conflict of interests: nothing to declare.

\section{Abstract}

Introduction: The Non Communicable Diseases (NCD) are the main causes of death in, having known, avoidable the Risk Factor (RF) and susceptible to intervention. Objective: Identify the prevalence of RF and protection for NCD in the Belo Horizonte, 2008. Methodology: Data were analyzed from Vigitel, in Belo Horizonte, 2008. They are presented to the frequencies of RF according to gender, schooling, and calculated the p-value and the PR. Results: Men showed more frequencie in the following RF: higher consumption of meat and milk with fats, soft drinks, abusive consumption of alcohol, drive after drinking, ex-smokers. Men presented in relation to protective factors statistically significant differences in consumption of beans and leisure-time physical activity. Women had the highest frequencies in the consumption of fruits and vegetables, protection against ultraviolet radiation, self-assessment of health as poor, and declared more morbidities such as: arterial hypertension, dyslipidemia, asthma and osteoporosis. Adults with low levels of education compared with high education (reference) presented the following PR: smoke PR 2.09 (95\%CI 1.43 - 3.05); consumption of 20 cigarettes and more PR 2.54 (95\%CI 1.19 - 5.43); overweight PR 1.27 (95\%CI 1.02 - 1.56); obesity PR 1.6 (95\%CI 1.04 - 2.47); consumption of soft drinks PR 2,07 (95\%CI $1.51-2.83$ ); consumption of fruit and vegetable intake PR 0.53 (95\%CI 0.40 - 0.72); consumption of beans PR 1.15 (95\%CI 1.05 - 1.27); watch TV PR 1.33 (95\%CI 1.00 - 1.77); driving after alcohol consumption PR 0.14 (95\%CI 0.04 - 0.53); hypertension PR 1.75 (95\%CI 1.37 - 2.24); diabetes PR 2.24 (95\%CI 1.23 - 4.09). Conclusion: The telephone surveys are an important method to monitor the distribution of risk and protective factors in the population and to permit to orient health promotion programs and prevention.

Keywords: Risk Factors. Non Communicable Diseases. Health Insurance. Monitoring. Surveillance. 


\section{Resumo}

Introdução: As Doenças Crônicas Não Transmissíveis (DCNT) são as principais causas de morte, tendo os Fatores de Risco (FR) conhecidos, evitáveis e passíveis de intervenção. Objetivo: Identificar a prevalência dos FR e proteção para DCNT em Belo Horizonte, 2008. Metodologia: Foram analisados dados do Vigitel, para Belo Horizonte, 2008. São apresentados as frequências dos FR segundo sexo, escolaridade, sendo calculados o valor de p e a RP. Resultados: Os homens apresentaram maior prevalência dos seguintes FR: consumo de carne e leite com gorduras, refrigerantes, consumo abusivo de bebida alcoólica, dirigir após beber, ex-fumantes. Homens também apresentaram diferenças estatisticamente significativas em relação aos fatores de proteção como: consumo de feijão e atividade física no tempo livre. Mulheres apresentaram maiores frequências no consumo de FVL, proteção contra a radiação ultravioleta, autoavaliação de saúde ruim, e declararam mais morbidades como: HA, dislipidemia, asma e osteoporose. Adultos com baixa escolaridade comparados com elevada escolaridade (referência) apresentaram as seguintes RP: fumo RP 2,09 (IC95\% 1,43 - 3,05); consumo de 20 cigarros e mais RP 2,54 (IC95\% 1,19 - 5,43); excesso de peso RP 1,27 (IC95\% 1,02 - 1,56); obesidade RP 1,6 (IC95\% 1,04 - 2,47); consumo de refrigerantes RP 2,07 (IC95\% 1,51 - 2,83); consumo de FVL como recomendado RP 0,53 (IC95\% 0,40 - 0,72); consumo de feijão RP 1,15 (IC95\% 1,05 - 1,27); assistir TV RP 1,33 (IC95\% 1,00 - 1,77); dirigir após consumo de álcool RP 0,14 (IC95\% 0,04 - 0,53); hipertensão arterial RP 1,75 (IC95\% 1,37 - 2,24); diabetes RP 2,24 (IC95\% 1,23 - 4,09). Conclusão: Os inquéritos telefônicos são um importante método para monitorar a distribuição dos FR e proteção na população, permitindo orientar programas de promoção à saúde e de prevenção.

Palavras-chave: Fatores de Risco. Doenças Crônicas. Monitoramento. Vigilância.

\section{Introduction}

A change in the characteristics of diseases was observed among the population, with a reduction of infectious disease and an increase of non-communicable chronic disease (NCCD). The NCCD are responsible for more than $72 \%$ of the deaths in Brazil, with the cardiovascular disease (CVD) being the main cause of death, representing almost one-third of the deaths in the country ${ }^{1}$. The NCCD are distinguished due to their high prevalence and for having risk factors (RF) that are possible to avoid, prevent and control $^{2}$.

Individuals who possess risk factors become the main target of disease and hazard prevention practices, as well as the health promotion practices. The objective of these practices is to attain quality of life and reduce health risks, providing improvements in the way of living ${ }^{3-5}$.

Regarding NCCD, it becomes necessary to identify the frequency and distribution of risk factors in the population to direct action and guide policies of health promotion. Health surveillance is an important strategy in the supervision of risk factors in the population and identification of priority population to direct action ${ }^{1,5,6}$.

Population survey is the strategy that is most used in the monitoring of risk factors. This is one of the most traditional methods used to get information on the health-disease process of the population ${ }^{7,8}$.

The United States conduct a system of surveillance by phone interviews, called as Behavioral Risk Factor Surveillance System (BRFSS). It was created in 1984 by the Centers of Disease Control and Prevention of the United States, and is the oldest system of surveillance by phone interview in the world ${ }^{9}$.

In Brazil, the risk factors and NCCD protection monitoring of the entire population was initiated by the Ministry of Health in 2003, by means of domiciliary and complemented survey in 2006, in all the state capitals and federal district, by means of the Risk Factors Surveillance and Chronic Disease Protection through Phone Survey (VIGITEL) program ${ }^{5,8}$. 
VIGITEL is a system of surveillance through phone that makes possible the monitoring of the Brazilian population for the NCCD risk factors. About 54.000 surveys are done annually among adults in the Brazilian capitals, by means of random selection of numbers from the landlines. This monitoring makes it possible to verify the frequencies of the main RF, quickly and at a low cost, and offers NCCD protection to the adult population ${ }^{5,10,11}$. The questionnaire used in the surveys approaches the demographic and socioeconomic characteristics of feeding, physical activities, weight and height pattern; smoking; alcoholic consumption; self-assessment of the state of health; cancer and related morbidity prevention among others ${ }^{5,11}$.

The objective of this study was to identify the prevalence of the risk factors and NCCD protection, in the population of Belo Horizonte, in the year 2008.

\section{Methodology}

This is an epidemiologic study, descriptive and transversal, on the basis of population. The research data were collected by the Ministry of Health, by means of the VIGITEL system, from the Belo Horizonte capital in the year 2008.

Adults, 18 years and older, living in domiciles with at least one landline available were interviewed. The VIGITEL system establishes a sample size of 2.000 surveys in adults by capital, so that is possible to estimate with a safe rate of $95 \%$ and maximum error of about $2 \%$ points, the frequency of any risk factor in the adult population ${ }^{5,11}$.

In Belo Horizonte, in 2008, about 5.000 phone lines were randomly picked, in a systematic and stratified way according to the region or number prefix of the phone lines, from registered landlines. The drafted lines were divided into little samples or replicas of 200 lines each, and were used until about 2.000 surveys were done. The participant domiciles of the sample were made at the first contact; adults were enumerated and one of them was drawn for the survey ${ }^{5,11}$. In 2008, 17 replicas of 3400 phone lines were used in
Belo Horizonte, of which 2570 were eligible, and a total of 2016 surveys were carried out on 799 men and 1217 women.

VIGITEL uses specific factors of balance, from the socio-demographic distribution (sex, age, and schooling) of the census in 2000, in order to represent the total adult population of the cities. Another factor of balance, takes into consideration the number of phone lines in the same residence and the number of adults in the draftee residence. Other information on methodology can be seen in other publications ${ }^{5,11}$.

The VIGITEL questionnaire, in 2008, had two parts: the first one identified the interviewee, the second one had questions referring to the food, physical activity, smoking, alcohol consumption, self-referred morbidity, self-referred weight and height, health situation, among other issues ${ }^{5}$.

VIGITEL 2008 data with reference to Belo Horizonte capital was requested from the Ministry of Health, Health Situation Analysis Department, Health Surveillance Secretariat, Non-communicable Diseases and Hazards Coordination, to the accomplishment of the study, which was granted.

For data processing and statistical analyses, an application called STATA, version 9, was used employing commands that estimate the confidence intervals of $95 \%$ to the balanced proportions by weights after stratification $^{5,12}$. The results according to sex were presented in percents and its respective confidence intervals $95 \% \mathrm{CI}$, and were calculated the prevalence ratio (PR) adjusted by school age.

The prevalence of the following risk factors and protection was calculated: smoking (individuals who smoke, independent of the frequency and intensity of smoking); ex-smokers (individuals who had smoked in the past and had stopped smoking, independent of the time); more than 20 cigarettes per day consumption (individuals who smoked more than 20 cigarettes per day); abusive alcohol consumption (individuals who, in the last 30 days, had consumed, four and more doses of alcoholic drinks in any one day, if women, and five doses or more, if 
men); driving after alcohol consumption (individuals who drove after consuming alcohol in the last 30 days); overweight (individuals with Index of Corporal Mass (IMC) equal to or more than $25 \mathrm{~kg} / \mathrm{m}^{2}$ ); obesity (individuals with IMC equal to or more than $\left.30 \mathrm{~kg} / \mathrm{m}^{2}\right)$; meats with fat excess consumption (individuals who eat fatty red meat or chicken meat with skin without removing the visible fat of the food); soda consumption (individuals who drink more than five days a week); whole milk consumption (individuals who drink whole milk with high fat); regular consumption of fruits, greens and vegetables (FGV) (individuals who eat FGV more than five days a week); recommended FGV consumption (individuals who consume five or more FGV daily portions); beans consumption (individuals who eat beans five or more days a week); physical inactivity (individuals who had not practiced any physical activity of leisure in the last three months, had not carried out intense physical work, had not traveled to work on foot or by bicycle and had not been responsible for the "heavy cleaning" of their houses); time watching television (TV) (individuals who spend three hours or more per day watching TV); sufficiently active during the free time (leisure) (individuals who practice physical activities of light or moderate intensity for at least 30 minutes per day for five or more days a week or activities of vigorous intensity for at least 20 minutes per day for three or more days a week); blood pressure (individuals who have been diagnosed with blood pressure earlier); diabetes (individuals who have previous medical diagnosis of diabetes); dyslipidemia (individuals who have medical diagnosis of dyslipidemia); osteoporosis (individuals who have medical diagnosis of osteoporosis); asthma, emphysema or bronchitis (individuals who have medical diagnosis of asthma, emphysema or bronchitis) and protection against ultraviolet rays (UV) (individuals who protect themselves from UV rays after 30 minutes of solar exposure ${ }^{5}$.

Due to our phone surveys, the free and clarified consent term was replaced by a verbal consent gotten in each phone call with the interviewed people. This consent was obtained by the Ministry of Health at the time of the survey. The project of VIGITEL implantation was approved by the Ethics in Research National Committee for Human Beings of the Ministry of Health ${ }^{5}$.

\section{Results}

Table 1 shows the percentage of adults by variable, $95 \% \mathrm{CI}$ according to sex, in Belo Horizonte. The percentage of smokers in Belo Horizonte was $18.8 \%$ (95\%CI 14.8 - 22.9), $21.1 \%$ (95\%CI 18.7 - 23.7) of ex-smokers and $7.9 \%$ (95\%CI $3.9-11.7$ ) of those who had smoked more than 20 cigarettes a day. Difference between the sexes was verified only between ex-smokers, and a predominance of men was proved. It was observed that $43.3 \%(95 \%$ CI $39.5-47.2)$ of the population was overweight and $12 \%(95 \% \mathrm{CI}$ 9.8 - 14.3) was obese; difference between the sexes was not verified for these factors.

Regarding food habits, $39.2 \%$ (95\%CI 35.7 - 42.6) of the population had consumed FGV regularly, 22.2\% (95\%CI 19.5 - 25.0) had consumed five or more daily portions of FGV, 41.8\% (95\%CI 37.9 - 45.7) had consumed meats with fat excess, $54.2 \%$ (95\%CI 50.3 - 58.1) had consumed whole milk, $27.5 \%$ (95\%CI 23.4-31.6) had consumed soda five or more days a week, $82.3 \%$ (95\%CI 78.9 - 85.5) had consumed beans regularly. Healthy food consumption practice, except beans, was higher between the women.

Regarding physical activities, in the population of Belo Horizonte, 16.8\% (95\%CI 14.2 - 19.3) indulged in physical activity during free time, $16.2 \%$ (95\%CI 13.8 - 18.6) were physically inactive and $24.3 \%$ (95\%CI 21.4 - 27.2) watched TV for three or more hours per day. The men practice more physical activity during free time (leisure).

The percentage of abusive alcoholic consumption in last the 30 days and of driving motorized vehicles after alcohol consumption was higher between men.

It was verified that $3.0 \%(95 \% \mathrm{CI} 2.2-3.9)$ of the population had evaluated their health 
Table 1 - Distribution* of risk and protective factors of non communicable diseases in adult ( $\geq 18$ year of age) in Belo Horizonte, by sex, VIGITEL, 2008.

Tabela 1 - Distribuição* de fatores de risco e proteção para doenças crônicas não transmissíveis em adultos ( $\geq 18$ anos) em Belo Horizonte, segundo sexo, VIGITEL, 2008.

\begin{tabular}{|c|c|c|c|c|c|c|c|}
\hline \multirow{2}{*}{ Variables } & \multicolumn{2}{|r|}{ Male } & \multicolumn{2}{|r|}{ Female } & \multicolumn{2}{|r|}{ Total } & \multirow{2}{*}{ p-value } \\
\hline & PR & $95 \% \mathrm{Cl}$ & PR & $95 \% \mathrm{Cl}$ & PR & $95 \% \mathrm{Cl}$ & \\
\hline Smokers & 20.63 & $16.21-25.06$ & 17.20 & $10.44-23.95$ & 18.84 & $14.78-22.91$ & 0.12 \\
\hline Ex-smokers & 26.31 & $22.40-30.22$ & 16.43 & $13.46-19.40$ & 21.17 & $18.67-23.66$ & 0.00 \\
\hline 20 or more cigarettes a day & 8.31 & $5.40-11.22$ & 7.43 & $0.48-14.37$ & 7.85 & $3.99-11.71$ & 0.50 \\
\hline Overweight adults & 46.71 & $41.80-51.62$ & 40.24 & $34.24-46.24$ & 43.34 & $39.47-47.21$ & 0.10 \\
\hline Adults with obesity & 11.49 & $8.11-14.87$ & 12.59 & $9.55-15.63$ & 12.06 & $9.81-14.32$ & 0.63 \\
\hline Fruits, greens and vegetables regularly & 32.43 & $27.66-37.20$ & 45.37 & $39.93-50.82$ & 39.17 & $35.69-42.64$ & 0.00 \\
\hline Fruits, greens and vegetables as recommended & 19.27 & $15.16-23.38$ & 25.00 & $21.12-28.88$ & 22.25 & $19.49-25.02$ & 0.02 \\
\hline Meats with visible fat & 48.56 & $43.61-53.51$ & 35.58 & $29.43-41.74$ & 41.81 & $37.88-45.73$ & 0.00 \\
\hline Milk with fat & 60.08 & $55.26-64.91$ & 48.75 & $43.05-54.45$ & 54.19 & $50.26-58.11$ & 0.01 \\
\hline Soda five and more a week & 32.60 & $27.58-37.62$ & 22.76 & $16.26-29.27$ & 27.48 & $23.39-31.57$ & 0.01 \\
\hline Beans five or more days a week & 88.12 & $84.92-91.31$ & 76.90 & $71.46-82.35$ & 82.28 & $78.98-85.58$ & 0.00 \\
\hline Physical activity during free time (leisure) & 21.33 & $17.03-25.63$ & 12.57 & $10.02-15.12$ & 16.77 & $14.23-19.31$ & 0.00 \\
\hline Physically inactive & 17.09 & $13.16-21.02$ & 15.31 & $12.47-18.15$ & 16.16 & $13.76-18.57$ & 0.33 \\
\hline To watch television & 22.39 & $18.29-26.49$ & 26.11 & $21.92-30.31$ & 24.33 & $21.42-27.24$ & 0.48 \\
\hline Abusive consumption of alcoholic drink & 30.61 & $26.05-35.17$ & 12.76 & $9.95-15.57$ & 21.32 & $18.52-24.11$ & 0.00 \\
\hline To drive after consuming alcohol & 3.49 & $2.15-4.83$ & 0.17 & $-0.01-0.36$ & 1.76 & $1.11-2.42$ & 0.00 \\
\hline Bad health self-assessment & 1.63 & $0.80-2.46$ & 4.42 & $2.90-5.94$ & 3.08 & $2.20-3.96$ & 0.01 \\
\hline Protection against ultraviolet rays & 28.69 & $24.44-32.95$ & 57.30 & $51.37-63.23$ & 43.58 & $39.86-47.31$ & 0.00 \\
\hline Blood pressure & 21.06 & $17.56-24.55$ & 26.77 & $22.79-30.75$ & 24.03 & $21.40-26.65$ & 0.00 \\
\hline Diabetes & 4.36 & $2.78-5.94$ & 4.91 & $3.42-6.39$ & 4.64 & $3.56-5.72$ & 0.27 \\
\hline Dyslipidemia & 12.68 & $9.98-15.38$ & 21.52 & $15.08-27.95$ & 17.28 & $13.56-21.00$ & 0.00 \\
\hline Asthma, bronchitis or emphysema & 2.63 & $1.57-3.69$ & 6.33 & $4.55-8.11$ & 4.56 & $3.51-5.61$ & 0.00 \\
\hline Osteoporosis & 0.95 & $0.10-1.81$ & 5.89 & $4.36-7.42$ & 3.52 & $2.65-4.40$ & 0.00 \\
\hline
\end{tabular}

RP: prevalence ratio.

*Weighted proportion according to the 2000 Census sociodemographic distribution of the adult population in each given state capital.

RP: Razão de prevalência.

*Percentual ponderado para ajustar a distribuição sociodemográfica da amostra VIGITEL à distribuição da população adulta da cidade no Censo Demográfico de 2000 5.

state as bad, and this percentage was higher among the women $(4.4 \%, 95 \% \mathrm{CI} 2.9-5.9)$.

The prevalence of blood pressure (BP) was $24 \%$ (95\%CI $21.4-26.6$ ); diabetes $4.6 \%$ (95\%CI 3.6 - 5.7); asthma, emphysema and bronchitis 4.6\% (95\%CI 3.5 - 5.6); osteoporosis $3.5 \%$ (95\%CI 2.6 - 4.4) and dyslipidemia $17.3 \%$ (95\%CI 13.6 - 21.0). Women had shown a higher prevalence of blood pressure, asthma, emphysema and bronchitis, dyslipidemia and osteoporosis. The frequency of protection against UV rays was $43.6 \%$ (95\%CI 39.9 - 47.3), and this factor was higher among women.

Tables 2 and 3 present the risk factors according to the schooling, adjusted by age. Adults with low schooling level (from 0 to 8 years of study) when compared with those of high schooling (12 and more years of study) had presented the following prevalence ratio (PR) statistically significant: smoking PR 2.09 (95\%CI 1.43 - 3.05); consumption of 20 cigarettes and more PR 2.54 (95\%CI 1.19 - 5.43); overweight PR 1.27 (95\%CI 1.02 - 1.56); obesity PR 1.6 (95\%CI 1.04 - 2.47); soda consumption PR 2.07 (95\%CI 1.51 - 2.83); regular consumption of FGV PR 0.62 (95\%CI 0.51 - 0.76); FGV recommended consumption PR 0.53 (95\%CI 0.40 - 0.72); meats with fat PR 1.64 (95\%CI 1.32 - 2.03); beans consumption PR 1.15 (95\%CI 1.05 - 1.27); watching TV PR 1.33 (95\%CI 1.00 - 1.77); driving after alcohol consumption PR 0.14 (95\%CI 0.04 - 0.53); blood pressure PR 1.75 (95\%CI 1.37 - 2.24); diabetes RP 2.24 (95\%CI 1.23 - 4.09); asthma, 
Table 2 - Frequency distribution* of risk and protective factors of non communicable chronic diseases in adult ( $\geq 18$ year of age) in Belo Horizonte, by education, VIGITEL, 2008.

Tabela 2 - Distribuição* de fatores de risco e proteção para doenças crônicas não transmissíveis em adultos ( $\geq 18$ anos) em Belo Horizonte, segundo escolaridade, VIGITEL, 2008.

\begin{tabular}{|c|c|c|c|c|c|c|}
\hline \multirow{3}{*}{ Variables } & \multicolumn{6}{|c|}{ Years of education } \\
\hline & \multicolumn{2}{|r|}{0 to 8} & \multicolumn{2}{|c|}{9 to 11} & \multicolumn{2}{|r|}{$\geq 12$} \\
\hline & PR & $95 \% \mathrm{Cl}$ & PR & $95 \% \mathrm{Cl}$ & PR & $95 \% \mathrm{Cl}$ \\
\hline Smokers & 24.92 & $17.21-32.63$ & 13.39 & $10.72-16.07$ & 12.66 & $9.44-15.89$ \\
\hline Ex-smokers & 23.88 & $19.22-28.54$ & 19.17 & $16.08-22.25$ & 17.72 & $14.14-21.29$ \\
\hline 20 or more cigarettes a day & 11.84 & $4.25-19.42$ & 3.61 & $2.15-5.07$ & 4.85 & $2.60-7.09$ \\
\hline Overweight adults & 50.18 & $43.03-57.32$ & 36.43 & $32.48-40.38$ & 37.63 & $32.87-42.38$ \\
\hline Adults with obesity & 15.95 & $11.58-20.32$ & 7.71 & $5.71-9.72$ & 9.47 & $6.54-12.40$ \\
\hline Fruits, greens and vegetables regularly & 33.29 & $27.22-39.36$ & 40.52 & $36.47-44.56$ & 51.39 & $46.54-56.25$ \\
\hline Fruits, greens and vegetables as recommended & 17.78 & $13.04-22.53$ & 23.47 & $19.93-27.01$ & 31.25 & $26.84-35.65$ \\
\hline Carnes com gordura visível & 47.54 & $40.33-54.75$ & 40.90 & $36.81-44.98$ & 29.22 & $24.79-33.66$ \\
\hline Leite com gordura & 54.29 & $46.89-61.70$ & 58.09 & $54.02-62.17$ & 47.70 & $42.85-52.55$ \\
\hline Refrigerante cinco ou mais dias por semana & 30.98 & $23.27-38.70$ & 29.51 & $25.68-33.35$ & 15.68 & $12.09-19.26$ \\
\hline Beans five or more days a week & 84.85 & $78.49-91.22$ & 84.51 & $81.64-87.38$ & 72.44 & $68.19-76.70$ \\
\hline Physical activity during free time (leisure) & 15.52 & $11.00-20.04$ & 17.88 & $14.63-21.12$ & 18.06 & $14.37-21.76$ \\
\hline Physically inactive & 14.76 & $10.62-18.90$ & 16.00 & $12.78-19.23$ & 19.86 & $15.83-23.90$ \\
\hline To watch television & 27.38 & $21.91-32.84$ & 23.20 & $19.72-26.68$ & 18.67 & $14.95-22.38$ \\
\hline Abusive consumption of alcoholic drink & 19.00 & $14.08-23.91$ & 24.40 & $20.72-28.08$ & 22.09 & $18.15-26.04$ \\
\hline To drive after consuming alcohol & 0.29 & $-0.12-0.71$ & 2.79 & $1.26-4.31$ & 3.73 & $1.86-5.61$ \\
\hline Bad health self-assessment & 3.33 & $1.84-4.82$ & 3.12 & $1.78-4.45$ & 2.42 & $0.98-3.85$ \\
\hline Protection against ultraviolet rays & 36.39 & $29.59-43.19$ & 46.44 & $42.31-50.56$ & 56.64 & $51.80-61.48$ \\
\hline Blood pressure & 32.60 & $27.16-38.05$ & 16.34 & $13.49-19.20$ & 15.29 & $11.92-18.65$ \\
\hline Diabetes & 6.68 & $4.59-8.76$ & 2.95 & $1.72-4.18$ & 2.36 & $1.12-3.61$ \\
\hline Dyslipidemia & 23.85 & $16.73-30.98$ & 9.88 & $7.72-12.03$ & 12.98 & $9.89-16.07$ \\
\hline Asma, bronquite ou enfisema & 2.75 & $1.49-4.01$ & 6.99 & $4.77-9.22$ & 5.11 & $3.01-7.20$ \\
\hline Osteoporosis & 5.66 & $3.89-7.43$ & 2.05 & $1.14-2.95$ & 0.65 & $0.18-1.12$ \\
\hline
\end{tabular}

RP: prevalence ratio.

*Weighted proportion according to the 2000 Census sociodemographic distribution of the adult population in each given state capital.

RP: Razão de prevalência.

*Percentual ponderado para ajustar a distribuição sociodemográfica da amostra VIGITEL à distribuição da população adulta da cidade no Censo Demográfico de 20005.

emphysema and bronchitis RP $0.42(95 \% \mathrm{CI}$ 0.23 - 0.75), osteoporosis PR 5.0 (95\%CI $2.27-11.02)$ and protection against UV rays PR 0.65 (95\%CI $0.53-0.80)$.

\section{Discussion}

NCCDs are most common diseases worldwide, which makes it necessary to extend the studies about their occurrence, as well as the risk factors among the population ${ }^{1,2}$. Phone enquiry is an important method in monitoring the distribution of the risk factors and protection in the population and it helps guide health promotion programs and chronic disease prevention ${ }^{8}$.
Among the factors monitored in the adult population in Belo Horizonte, the men had shown statistical and significant differences in the following risk factors: a higher consumption of meat with fat, whole milk with fat, soda, abusive alcohol consumption, driving after consuming alcohol, ex-smokers and among the protection factors: higher beans consumption and physical activity during free time. Women had shown a higher FGV consumption and higher protection against the UV rays. Among the risk factors, women had declared more morbidity, as blood pressure, dyslipidemia, asthma and osteoporosis, and had presented a higher frequency of bad health self-assessment. Adults with low schooling 
Table 3 - Prevalence Ratio of risk and protective factors of non communicable diseases in adult ( $\geq 18$ year of age) in Belo Horizonte, by education, VIGITEL, 2008.

Tabela 3 - Razão de Prevalência de fatores de risco e proteção para doenças crônicas não transmissíveis em adultos ( $\geq 18$ anos) em Belo Horizonte, segundo escolaridade, VIGITEL, 2008.

\begin{tabular}{|c|c|c|c|c|c|c|c|}
\hline \multirow{3}{*}{ Variables } & \multicolumn{7}{|c|}{ Years of education } \\
\hline & \multicolumn{3}{|c|}{0 to 8} & \multicolumn{3}{|c|}{9 to 11} & \multirow{2}{*}{$\begin{array}{r}\geq 12 \\
P R\end{array}$} \\
\hline & PR & $p$-value & $95 \% \mathrm{Cl}$ & PR & p-value & $95 \% \mathrm{Cl}$ & \\
\hline Smokers & 2.09 & 0.00 & $1.43-3.05$ & 0.98 & 0.90 & $0.71-1.36$ & 1.00 \\
\hline Ex-smokers & 1.09 & 0.51 & $0.84-1.43$ & 1.21 & 0.13 & $0.95-1.54$ & 1.00 \\
\hline 20 or more cigarettes a day & 2.54 & 0.02 & $1.19-5.43$ & 0.66 & 0.20 & $0.35-1.24$ & 1.00 \\
\hline Overweight adults & 1.27 & 0.03 & $1.02-1.56$ & 1.03 & 0.71 & $0.87-1.22$ & 1.00 \\
\hline Adults with obesity & 1.60 & 0.03 & $1.04-2.47$ & 0.86 & 0.48 & $0.58-1.29$ & 1.00 \\
\hline Fruits, greens and vegetables regularly & 0.62 & 0.00 & $0.51-0.76$ & 0.84 & 0.01 & $0.73-0.96$ & 1.00 \\
\hline Fruits, greens and vegetables as recommended & 0.53 & 0.00 & $0.40-0.72$ & 0.78 & 0.02 & $0.64-0.96$ & 1.00 \\
\hline Meats with visible fat & 1.64 & 0.00 & $1.32-2.03$ & 1.36 & 0.00 & $1.13-1.63$ & 1.00 \\
\hline Leite com gordura & 1.16 & 0.09 & $0.98-1.37$ & 1.19 & 0.01 & $1.05-1.35$ & 1.00 \\
\hline Soda five or more days a week & 2.07 & 0.00 & $1.51-2.83$ & 1.66 & 0.00 & $1.28-2.16$ & 1.00 \\
\hline Beans five or more days a week & 1.15 & 0.00 & $1.05-1.27$ & 1.17 & 0.00 & $1.09-1.25$ & 1.00 \\
\hline Physical activity during free time (leisure) & 0.78 & 0.17 & $0.54-1.12$ & 0.95 & 0.73 & $0.73-1.24$ & 1.00 \\
\hline Physically inactive & 0.72 & 0.06 & $0.52-1.01$ & 0.85 & 0.27 & $0.64-1.14$ & 1.00 \\
\hline To watch television & 1.33 & 0.05 & $1.00-1.77$ & 1.33 & 0.02 & $1.04-1.70$ & 1.00 \\
\hline Abusive consumption of alcoholic drink & 0.85 & 0.30 & $0.62-1.16$ & 1.02 & 0.85 & $0.81-1.29$ & 1.00 \\
\hline To drive consuming alcohol & 0.14 & 0.00 & $0.04-0.53$ & 0.65 & 0.23 & $0.32-1.31$ & 1.00 \\
\hline Bad health self-assessment & 1.50 & 0.27 & $0.74-3.03$ & 1.50 & 0.28 & $0.72-3.10$ & 1.00 \\
\hline Protection against ultraviolet rays & 0.65 & 0.00 & $0.53-0.80$ & 0.83 & 0.00 & $0.73-0.94$ & 1.00 \\
\hline Blood pressure & 1.75 & 0.00 & $1.37-2.24$ & 1.21 & 0.16 & $0.93-1.58$ & 1.00 \\
\hline Diabetes & 2.24 & 0.01 & $1.23-4.09$ & 1.55 & 0.19 & $0.80-2.98$ & 1.00 \\
\hline Dyslipidemia & 1.54 & 0.06 & $0.98-2.43$ & 0.84 & 0.28 & $0.61-1.15$ & 1.00 \\
\hline Asthma, bronchitis or emphysema & 0.42 & 0.00 & $0.23-0.75$ & 1.38 & 0.21 & $0.83-2.29$ & 1.00 \\
\hline Osteoporosis & 5.00 & 0.00 & $2.27-11.02$ & 4.00 & 0.00 & $1.76-9.10$ & 1.00 \\
\hline
\end{tabular}

Prevalence ratio (RP) adjusted by age.

*Weighted proportion according to the 2000 Census sociodemographic distribution of the adult population in each given state capital.

Razão de prevalência (RP) ajustada por idade.

*Percentual ponderado para ajustar a distribuição sociodemográfica da amostra VIGITEL à distribuição da população adulta da cidade no Censo Demográfico de $2000^{5}$.

level compared with those of high schooling level had presented higher PR in smoking 20 cigarettes and more a day, overweight, obesity, soda consumption, meats with fat consumption, watching TV, blood pressure, diabetes, dyslipidemia, osteoporosis and lower PR in FGV consumption, ultraviolet rays protection and driving after consuming alcohol. Among the protection factors, individuals of low schooling levels are shown to eat more beans.

The differences between sex and schooling are important to guide the performance of the public policies and health professionals.
Global data show that obesity has grown in the world, resulting from non-healthy food and low levels of physical activity ${ }^{2}$.

About one in 40 people in North America are obese and the number is growing. In Brazil, the Family Budget Research (POF) estimation points that there are about $14 \%$ of obese people in the country and there is an increase in overweight trends and obesity ${ }^{13}$. Surveys at Campinas show similar findings to what has already been found in this study ${ }^{14}$.

Phone surveys in the United States, as the BRFSS ${ }^{9}$, had also identified low 
FGV consumption of five daily portions (24\%), next to what was described for Belo Horizonte. Literature also describes higher frequency of health food consumption between women, similar to the findings in Belo Horizonte ${ }^{13-16}$.

The low consumption of FGV can be a consequence of several factors, such as difficulty in accessing good quality food at low cost, besides cultural values that emphasize on the consumption of greasy food and food rich in sugars, consuming food from fast-foods restaurants, all of which can be detrimental to good health ${ }^{4,16}$. Jaime et al. ${ }^{16}$ had found an association between schooling and FGV consumption. This can be explained by high levels of information that individuals have and access to foods with better quality and cost.

The study points that the reduction in the fruits, greens and vegetables prices could increase the consumption of these foods by the population ${ }^{17}$. This shows the importance of having public policies that extend to health food production ${ }^{13}$.

In the population, we found an inverse association between the consumption of meats with excess fat and the schooling level. In Brazil, similar data were identified ${ }^{14,15}$.

Men are described in literature as being most active with regard to physical activity practice during free time ${ }^{19}$. Physical activity practice in leisure is associated in literature with higher schooling level ${ }^{19}$; however, in Belo Horizonte, when adjusted by age, this effect disappeared. Low schooling levels had shown higher PR only for TV time.

The prevalence of smoking in the United States $^{9}$ in 2007 was $18.3 \%$, similar to the findings described here. The Smoking National Research in 2008 also found an association between low schooling levels and higher smokers prevalence ${ }^{20}$. Tobacco is one of the most relevant risk factors for chronic disease, especially, the cardiovascular disease and lung cancer, making it important to invest in public policies focused on the reduction of smoking, bringing in regulatory measures, marketing prohibition, increasing prices of tobacco products and taking educational measures $^{14}$.

In relation to abusive alcohol consumption, BRFSS data ${ }^{9}$ show a percentage of $15.5 \%$, lesser than the data found in Belo Horizonte. It was also verified that men had consumed more alcoholic drinks than women. This finding was also confirmed in other studies ${ }^{5.21}$.

The frequency of self-assessment on the state of health as "bad," was higher among women, and adults with up to eight years of education. This finding is coherent with literature that points at worst evaluation of health between women and the aged ${ }^{15,22}$. Studies point at worst results regarding the state of health self-assessment between the aged, with low schooling, low income and carriers of chronic disease $\mathrm{e}^{23,24}$.

A study on blood pressure in Brazil ${ }^{25}$ has shown that there is no sex distinction, and that blood pressure increases with age advancement. Other studies on blood pressure prevalence had also found values more than $20 \%{ }^{26-29}$.

The data of the current study in Belo Horizonte, pointed at higher frequency of hypertension in women and prevalence of more than $20 \%$. Higher self-referred prevalence was also identified in women for dyslipidemia, asthma and osteoporosis. One of the explanations could be higher look for services, and, therefore, higher chances of diagnosis between women ${ }^{30}$. We also distinguished that the methodology used in the current study is related to the selfreport from a previous medical diagnosis. Therefore, the real prevalence should be confirmed in future investigations with the use of other methodologies.

It was verified that the women and adults with twelve years and more of education, protected themselves more against the ultraviolet rays. In Brazil, women also tended to adopt these measures to protect themselves more ${ }^{5}$.

Among the limitations of the work, we cited the fact of showing individuals who have landlines. This can reduce the participation of the low income population, especially 
in the poorest regions of the city. However, Belo Horizonte has a high coverage of fixed telephones, which reduces the problem. Moreover, the use of after stratification factors, corrects the estimations and minimizes possible differences ${ }^{5}$. Comparative studies between phone and domiciliary surveys carried out in Belo Horizonte had shown prevalence very close $^{31}$.

Considering the schooling level as a proxy of the population's socioeconomic condition, this level contributed to analyzing the population's condition of life and situation of health ${ }^{32}$. Thus, it was verified that the population of low schooling level presented less healthy way of life. The schooling level and the social environment have an influence on the behavior, and measures of health promotion, such as health food access, physical spaces access that promote physical activity practice, regulatory measures related to tobacco and alcohol, feeding and mass education, favor the individual choices of health habits ${ }^{4}$. The monitoring of the risk factors helps in identifying the population that is most vulnerable and has higher risk for the development of NCCD, supporting actions of disease prevention and health hazards and reducing inequalities.

\section{References}

1. Schmidt MI, Duncan BB, Azevedo e Silva G, Menezes AM, Monteiro CA, Barreto SM, et al. Health in Brazil 4. Chronic non-communicable diseases in Brazil: burden and current challenges. Lancet 2011; 377(9781): 1949-61.

2. World Health Organization. Global status report on noncommunicable diseases 2010. Geneva: World Health Organization; 2011.

3. Malta DC, Cezário AC, Moura L, Morais Neto OL, Silva Junior JB. A construção da vigilância e prevenção das doenças crônicas e agravos não transmissíveis no contexto do Sistema Único de Saúde. Epidemiolo Serv Saúde 2006; 15(3): 47-65.

4. Brasil. Plano de ações estratégicas para o enfrentamento das Doenças Crônicas Não Transmissíveis (DCNT) no Brasil. 2012-2022. Secretaria de Vigilância em Saúde. Brasília: Ministério da Saúde; 2011.

5. Brasil. Vigitel 2008. Vigilância de fatores de risco para doenças crônicas por inquérito telefônico 2008. Secretaria de Vigilância em Saúde. Brasília: Ministério da Saúde; 2008.

6. Lessa I. Doenças crônicas não transmissíveis no Brasil: um desafio para a complexa tarefa da vigilância. Cienc Saude Coletiva 2004; 9(4): 931-43.

7. Waldman EA, Novaes MD, Albuquerque MFM, Latorre MRDO, Ribeiro MCSA, Vasconcelos M, et al. Inquéritos populacionais: aspectos metodológicos, operacionais e éticos. Rev Bras Epidemiol 2008; 11(Suppl 1): 168-79.

8. Malta DC, Leal MC, Lima-Costa MF, Morais Neto OL. Inquéritos nacionais de saúde: experiência acumulada e proposta para o inquérito de saúde brasileiro. Rev Bras Epidemiol 2008; 11(Suppl 1): 159-67.

9. Centers Diseases Controls and Prevention. Behavioral Risk Factor Surveillance System. Prevalence and Trends Data, 2007. Disponível em: http: //apps.nccd.cdc.gov/BRFSS/page.asp?cat=X $\mathrm{X} \& \mathrm{yr}=2007 \&$ state=All\#XX (acessado em 30 de outubro de 2009).
10. Brasil, Ministério da Saúde. Saúde Brasil 2008: uma análise da situação de saúde no Brasil. Brasília: Ministério da Saúde, 2009.

11. Moura EC, Morais Neto OL, Malta DC, Moura L, Silva NN. Vigilância de fatores de risco para doenças crônicas por inquérito telefônico nas capitais dos 26 estados brasileiros e no Distrito Federal (2006). Rev Bras Epidemiol 2008; 11(Suppl 1): 20-37.

12. Stata Corporation. Stata Statistical Software: Release 9.0. Stata Corporation: College Satation, TX; 2005.

13. Brasil. Instituto Brasileiro de Geografia e Estatística. Pesquisa de Orçamentos Familiares (POF) 2002-2003, primeiros resultados: Brasil e grandes regiões. 2003. Disponível em: http: //www.ibge.gov.br/home/estatistica/ populacao/condicaodevida/pof/2002/pof2002.pdf (acessado em 30 de oututro de 2009).

14. Barros MBA, César CLG, Carandina L, Goldbraum M. As dimensões da saúde: inquérito populacional em Campinas. São Paulo: Hucitec; 2008. 229 p.

15. Moura EC, Malta DC, de Morais Neto OL, Monteiro CA. Prevalence and social distribution of risk factors for chronic noncommunicable diseases in Brazil. Rev Panam Salud Publica 2009; 26(1): 17-22.

16. Jaime PC, Figueiredo ICR, Moura EC, Malta DC. Fatores associados ao consumo de frutas e hortaliças no Brasil, 2006. Rev Saude Publica 2009; 43(2): 57-64

17. Claro RM, Carmo HCE, Machado FSM, Monteiro CA. Renda, preço dos alimentos e participação de frutas e hortaliças na dieta. Rev Saude Publica 2007; 41(4): 557-64.

18. Figueiredo ICR, Jaime PC, Monteiro CA. Fatores associados ao consumo de frutas, legumes e verduras em adultos da cidade de São Paulo. Rev Saude Publica 2008; 42(5): 777-85. 
19. Hallal PC, Knuth AG, Reis RS, Rombaldi AJ, Malta DC, Iser BPM, et al. Tendências temporais de atividade física no Brasil (2006-2009). Rev Bras Epidemiol 2011; 14(1): 53-60.

20. Brasil, Instituto de Geografia e Estatística. Pesquisa Nacional do Tabagismo - PETAB. Suplemento Saúde da Pesquisa Nacional de Amostras de Domicílios 2008. Suplemento Saúde; 2009.

21. Moura EC, Malta DC. Consumo de bebidas alcoólicas na população adulta Brasileira: características sociodemográficas e tendência. Rev Bras Epidemiol 2011; 14(Suppl 1): 61-70.

22. Barros MBA, Zanchetta LM, Moura EC, Malta DC. Autoavaliação da saúde e fatores associados, Brasil, 2006. Rev Saude Publica 2009; 43(2): 27-37.

23. Lima-Costa MF, Matos DL, Camarano AA. Evolução das desigualdades sociais entre idosos e adultos brasileiros: um estudo baseado na Pesquisa Nacional por amostra de Domicílios (PNAD 1998-2003). Cienc Saude Coletiva 2006; 11(4): 941-50.

24. Stelmach W, Kaczmarczyk-Chałas K, Bielecki W, Drygas $\mathrm{W}$. The association between income, education, control over and health in a large urban population of Poland. Int J Occup Med Environ Health 2004; 17(2): 299-310.

25. Passos VMA, Assis TD, Barreto SM. Hipertensão arterial no Brasil: estimativa de prevalência a partir de estudos de base populacional. Epidemiol Serv Saúde 2006; 15(1): 35-45.

26. Feijão AMM, Gadelha FV, Bezerra AA, de Oliveira AM, Silva Mdo S, Lima JW. Prevalência de excesso de peso e hipertensão arterial em população urbana de baixa renda. Arq Bras Cardiol 2005; 84(1): 29-33.

27. Piccini RX, Victora CG. Hipertensão arterial sistêmica em área urbana no sul do Brasil: prevalência e fatores de risco. Rev Saude Publica 1994; 28(4): 261-7.

28. Trindade IS, Heineck G, Machado JR, Ayzemberg H, Formighieri M, Crestani, et al. Prevalência de hipertensão arterial sistêmica na população urbana de Passo Fundo. Arq Bras Cardiol 1998; 71(2): 127-30.

29. Ferreira SRG, Moura EC, Malta DC, Sarno F. Frequência de hipertensão arterial e fatores associados: Brasil, 2006. Rev Saude Publica 2009; 43(2): 98-106.

30. Lima-Costa MF, Peixoto SV, Firmo JOA. Validade da hipertensão arterial auto-referida e seus determinantes (Projeto Bambuí). Rev Saude Publica 2004,38: 637-42.

31. Ferreira AD, César CC, Malta DC, Andrade ACS, Ramos CGC, Proietti FA, et al. Validade de estimativas obtidas por inquérito telefônico: comparação entre VIGITEL 2008 e inquérito Saúde em Beagá. Rev Bras Epidemiol 2011; 4(1): 16-30.

32. Rede Interagencial de Informação em Saúde. Indicadores Básicos para a saúde no Brasil: conceitos e aplicações. RIPSA. Organização Pan Americana para a Saúde; 2008. Disponível em: http: //tabnet.datasus. gov.br/cgi/idb2006/CapituloB.pdf (acessado em 29 de dezembro de 2008).

Received on: 02/07/11

Final version presented on: 12/14/11

Accepted on: 02/16/12 